\title{
AN OVERVIEW OF POLLEN AND ANTHER WALL DEVELOPMENT IN Catalpa bignonioides Walter (BIGNONIACEAE)
}

\author{
Sevil TÜTÜNCÜ KONYAR \\ Trakya University, Faculty of Science, Department of Biology, 22030, Edirne, Turkey. \\ e-mail: seviltutuncu@gmail.com
}

Received (Alınıs): 29 Apr 2017, Accepted (Kabul): 17 Sep 2017, Online First (Erken Görünüm): 27 Sep 2017, Published (Basım): 15 Dec 2017

\begin{abstract}
Anther_development_in Catalpa bignonioides Walter was investigated from the sporogenous cell to the mature pollen grain stages to determine whether the pollen and anther wall development follows the basic scheme in angiosperms. In order to follow pollen ontogeny through successive stages of pollen development, anthers at different developmental stages were embedded in epon according to the usual method, and semi-thin sections, taken from the epon embedded anthers, were stained with toluidine blue for general histological observations under light microscopy. The young anther wall of $C$. bignonioides consists of four layers; from the exterior, the epidermis, endothecium, middle layer, and a secretory tapetum. The tapetum is dual in origin and dimorphic. Ubisch bodies were observed on the inner tangential walls of the tapetal cells. The number of the anther wall layers changes depending on the developmental stage and region of the anther. In contrast to the other anther wall layers, epidermis and endothecium layers remain intact until anthesis. Endothecial cells enlarge and develop thickenings at maturity. During microspore development, meiocytes undergo meiosis and simultaneous cytokinesis leading to the formation of permanent tetrahedral, isobilateral and rarely linear tetrads. Pollen tetrads are shed from the anther as compound pollen grains. Results of the study revealed that pollen and anther wall development in $C$. bignonioides follows the basic scheme in angiosperms.
\end{abstract}

Key words: Anther wall, Microspore development, Medicinal plants, Tetrad pollens.

\section{Catalpa bignonioides Walter (Bignoniaceae)'deki Polen ve Anter Çeperi Gelişimine Genel Bir Bakış}

\begin{abstract}
Özet: Catalpa bignonioides Walter'deki anter çeperi ve polen gelişiminin diğer angiospermlerdeki temel aşamaları takip edip etmediğini anlayabilmek için, bu bitkideki anter gelişimi sporogen evre aşamasından olgun polen aşamasına kadar 1 şık mikroskobu kullanılarak araştırıldı. Anterdeki polen ontogenezini sırasıyla takip edebilmek için farklı gelişim aşamalarındaki anterler epona gömüldü ve bu anterlerden ultramikrotom ile alınan 1 mikronluk kesitler genel histokimyasal gözlemler için toluidin mavisiyle boyandı. Catalpa bignonioides'in genç anter çeperi dıştan içe doğru sırasıyla epidermis, endotesyum, ara tabaka ve salgı tapetumu olmak üzere 4 farklı tabakadan oluşmaktadır. Tapetum hücreleri iki farklı kökenden gelir ve yapısal olarak dimorfiktir. Tapetum hücrelerinin dış çeperlerinde, Ubisch cisimcikleri gözlenmiştir. Anter çeperindeki tabaka sayısı anterin gelişim aşamalarına ve değişik bölgelerine göre farklılık göstermektedir. Epidermis ve endotesyum tabakaları, anter çeperinin diğer tabakalarından farklı olarak, anter açılmasına kadar bütünlüğ̈nü korumaktadır. Endotesyum hücreleri olgun polen aşamasında genişler ve çeper kalınlaşmaları gösterir. Mikrospor gelişimi sırasında mayoz bölünme geçiren hücreler simultane tip sitokinez ile tedrahedral, izobilateral ve nadir olarak da linear tipte kalıcı tetratları oluşturur. Polenler anterden tetrat halinde dışarı atılır. Bu çalışmanın bulguları C. bignonioides'teki anter çeperi ve polen gelişiminin diğer angiospermlerle uyumlu olduğunu göstermiştir.
\end{abstract}

Anahtar kelimeler: Anter çeperi, Mikrospor gelişimi, Tıbbi bitkiler, Tetrat polenler.

\section{Introduction}

Bignoniaceae family, whose members are mostly trees and shrubs and more rarely lianas and herbaceous plants, comprises some 82 genera with approximately 827 species (Olmstead et al. 2009) distributed primarily in tropical (greatest diversity in Brazil) and sub-tropical regions of America, Asia, and Africa. However, some species are also used worldwide as ornamentals (Castillo \& Rossini 2010). Catalpa Scop. is a small genus in Bignoniaceae comprising eight natural species and two hybrid species of perennial trees frequently used in horticulture as garden and street trees (Olsen \& Kirkbride 2017). It is the only genus in Bignoniaceae that is common to both the Old and the New Worlds, its members are distributed mostly in the tropics and subtropics with the center of diversity in South America (Deka et al. 2013). In Turkey, the genus Catalpa is represented by only one species, Catalpa bignonioides Walter, which is planted as street and garden tree. 
Bignoniaceae has long attracted the attention of scientists as a source of pharmacologically valuable active compounds. Therefore, numerous studies regarding phytochemicals have been carried on this family. These phytochemical studies have revealed that the extracts from Bignoniaceae species contain secondary metabolites such as tannins, flavonoids, quinones, alkaloids, triterpenes, steroids, and iridoids (de Abreu et al. 2014, Choudhury et al. 2011, Cragg \& Newman 2005) which have anti-inflammatory, antidiuretic, anti-arthritic, antimicrobial, antioxidant, anti-dysenteric, anti-diarrheal and anti-tumor activity (Choudhury et al. 2011). The genus Catalpa is also an important source of the medically valuable secondary metabolites. The fruits, flowers, bark, and leaves of the Catalpa plants are rich in many kinds of pharmacologically active compounds such as naphthoquinones (Inouye et al. 1975), flavonoids (Harborne 1967, Okuda et al. 1975) and phenolic acids (Nakaoki \& Morita 1955). Therefore, numerous species of Catalpa including C. bignonioides; $C$. ovata, $C$. bungei and $C$. speciosa are often used medicinally. For instance, C. bignonioides used in preparations with other herbs for the treatment of respiratory diseases such as whooping cough, asthma, and spasmodic coughs in children because of its sedative effect and mild narcotic action (Felter \& Lloyd 1989). C. bignonioides has also been described for the treatment of irritable ulcers (Munoz-Mingarro et al. 2003). Moreover, it has an antioxidant activity (Dvorská et al. 2007).

The Bignoniaceae family has also long attracted the attention of scientists concerning its taxonomic problems. The circumscription of Bignoniaceae and Scrophulariaceae has long been a taxonomic problem. Several genera have been variously placed in one or the other family (Armstrong 1985). Recently, the delimitation of Bignoniaceae genera and tribes has undergone major changes following an increased understanding of phylogenetic relationships within the family (Pace et al. 2015). However, to propose an ideal classification for Bignoniaceae, taxonomists need the data of the studies regarding the biochemistry, pollen analysis, micromorphology, anatomy, cytology, molecular phylogeny, embryology, and anther wall and pollen development.

In Bignoniaceae, studies concerning the ontogenic or histochemical development of pollen grains or anther wall are rare and include Campsis radicans (L.) Seem. (Tütüncü Konyar \& Dane 2013a, 2013b, Tütüncü Konyar et al. 2013, Tütüncü Konyar 2014), Catalpa bungei C.A. Mey. (Fan et al. 2011), Catalpa ovata G. Don (Ruwen 1981), Catalpa speciosa (Warder ex Barney) Warder ex Engelm. (Chen et al. 2014, Hai-Yan et al. 2013), Dolichandra unguis-cati (L.) L.G. Lohmann (Bignonia unguis-cati) (Shivaramiah 1981), Dolichandrone falcata (Wall. ex DC.) Seem., Jacaranda mimosifolia D. Don (Galati \& Strittmatter 1999), Markhamia lutea (Benth.) K. Schum (Dolichandrone platycalyx), (Shivaramiah 1981), Millingtonia hortensis L.f. (Mehra \& Kulkarni 1986),
Kigelia africana (Lam.) Benth (Kigelia pinnata) (Shivaramiah 1981), Oroxylum indicum (L.) Kurz (Ghatak 1956), Parmentiera aculeata (Kunth) L.O. Williams (Parmentiera edulis) (Shivaramiah 1981), Pyrostegia venusta (Ker-Gawl.) Miers (Pyrostegia ignea) (Gupta \& Nanda 1978), Spathodea campanulata Beauv. (Raghavan \& Venkatasubban 1940, Rudramuniyappa \& Mahajan 1991), Tecoma $x$ smithii Hort. (Shivaramiah 1981), Tecoma stans (L.) Juss. ex Kunth (Nanda \& Gupta 1978), Tabebuia ochracea A.H. Gentry, (Bittencourt Jr. 1996), Tabebuia pallida (Lindl.) Miers (Shivaramiah 1981), Tabebuia pulcherrima Sandwith (Bittencourt Jr. \& Mariath 1997), Tabebuia rosea (Bertol.) Bertero ex A. DC. (Mehra \& Kulkarni 1986). These earlier studies on anther ontogeny in Bignoniaceae have revealed that anther development in this family varies from species to species. Anther wall development is the dicotyledonous or basic type. The anthers are mostly tetrasporangiate and rarely bisporangiate. The endothecium is usually single layered but two to three layered endothecium are also found in some plants. The endothecium may or may not exhibit thickenings. The tapetum is either of the secretory or amoeboid type and usually single layered. Tapetal cells are usually binucleate or multinucleate, and rarely uninucleate as in K. pinnata (Shivaramiah 1981).

The studies of anther ontogeny in Bignoniaceae are inadequate in number as a source of comprehensive data on the distribution of taxonomic characters in different genera of this family. Therefore, Bignoniaceae family needs more embryological data on the taxonomically important characters concerning the anther wall and pollen development such as the number of anther wall layers, tapetum and tetrad type.

The primary aim of this study was (1) to determine whether the anther development in $C$. bignonioides follows the basic scheme in angiosperms, (2) to provide embryological data that will contribute to the understanding of the reproductive biology of $C$. bignonioides and (3) to provide taxonomically important data for Bignoniaceae which would contribute to the taxonomic and phylogenetic studies.

\section{Materials and Methods}

Fresh flower buds of different sizes and at different developmental stages were collected from $C$. bignonioides plant which was planted as an ornamental in parks and on the roadsides of Edirne A1 (E) in European Turkey (The development stages of anthers had been determined before by examining squash preparation stained with acetic carmine under a light microscope). Following dissection from the buds, 10 anthers at various developmental stages were prefixed immediately in $3 \%$ glutaraldehyde in Sorensen's buffer $(\mathrm{pH} 7.4)$ for $24 \mathrm{~h}$ at $4^{\circ} \mathrm{C}$ and rinsed in Sorensen's buffer three times for $15 \mathrm{~min}$ each. After postfixation with $1 \%$ osmium tetroxide in the same buffer $(\mathrm{pH} \mathrm{7.4)}$ for $2 \mathrm{~h}$ at room temperature, the anthers were dehydrated in a series of increasing concentration of ethanol in water and embedded in Epon according to the usual method (Craig et al. 1962). 1- $\mu \mathrm{m}$ 
transverse sections were cut from the Epon embedded anthers with Leica Em UC6 ultramicrotome and stained with toluidine blue for general histological observations.

\section{Toluidine blue staining}

Semi-thin sections of the Epon- embedded anthers were stained with toluidine blue to highlight cell components for general histological observations under light microscopy. For this purpose, semi-thin sections were stained with $1 \%$ toluidine blue at $60^{\circ} \mathrm{C}$ for $50 \mathrm{~min}$ and rinsed in distilled water for $2 \mathrm{~min}$. Toluidine blue stains nucleic acids (acidic polyanionic groups) blue and polysaccharides purple.

\section{Results}

\section{Anther wall}

Androecium of $C$. bignonioides is composed of five stamens two of which are fertile and the other three are staminode. The development of the anther wall is the dicotyledonous type. The fertile anthers of $C$. bignonioides are tetrasporangiate, and their wall comprises four different layers; from the exterior, the epidermis, endothecium, middle layer, and the secretory (glandular) tapetum. The number of anther wall layers ranges from three to six depending on the development stage and the region of the anther (Fig. 1A-H). The outermost layer of the anther wall, epidermis, remained intact until the end of the anther development, and cuticle layer was observed on the outer tangential wall of the epidermal cells (Fig. 1F-H). At the stomium regions, radially elongated epidermal cells were detected (Fig. 1F). Like epidermis, the endothecium also remained intact until the end of the anther development. The number of endothecium layers varied from 1 to 3 depending on the developmental stage and region of the anther. At the vacuolated and mature pollen grain stages, endothecial cells enlarged and developed U-shaped thickenings on their inner tangential and radial walls (Fig. 1E-I).

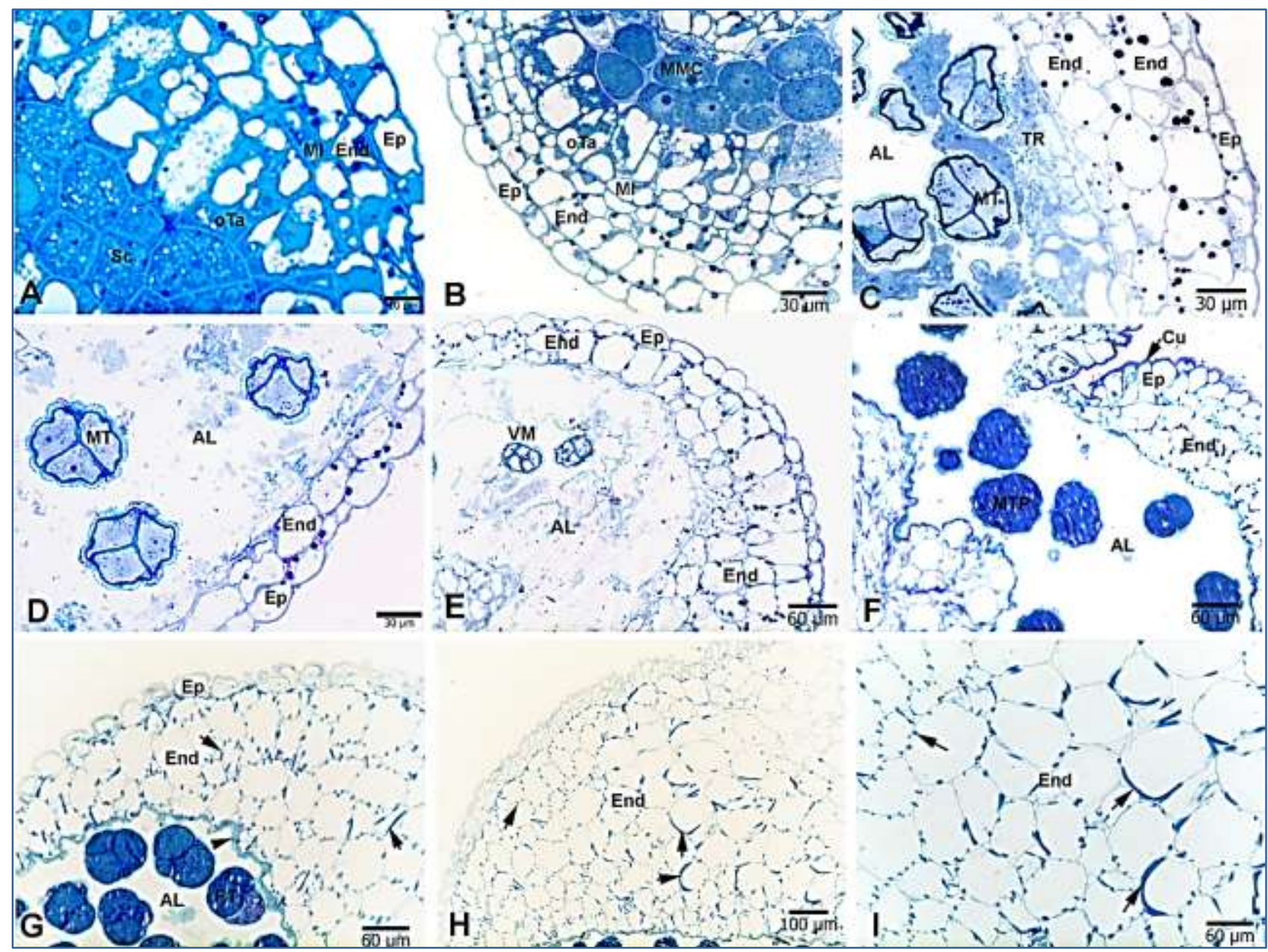

Fig. 1: Development of anther wall in $C$. bignonioides anthers during various phases of pollen ontogeny (Semi-thin sections stained with Toluidine blue). A- Sporogenous cell stage. B- Microspore mother cell stage. C, D- Free microspore tetrad stage. E- Vacuolated microspore tetrad stage. F, G- Mature pollen tetrad stage. Note the endothecial thickenings (arrows), and tapetal membrane studded with Ubisch bodies (arrowhead) in figure G, H, I- U-shaped endothecial thickenings (arrows) in the anther wall at anthesis stage. (ALanther locule, $\mathrm{Cu}$ - cuticle layer, End- endothecium, Ep- epidermis, Ml- middle layer, MT- microspore tetrad, MMC- microspore mother cell, PT- pollen tedrad, Sc- sporogenous cell, oTa- outer tapetum, TR- remnants of the tapetum, VM- vacuolated microspore). 


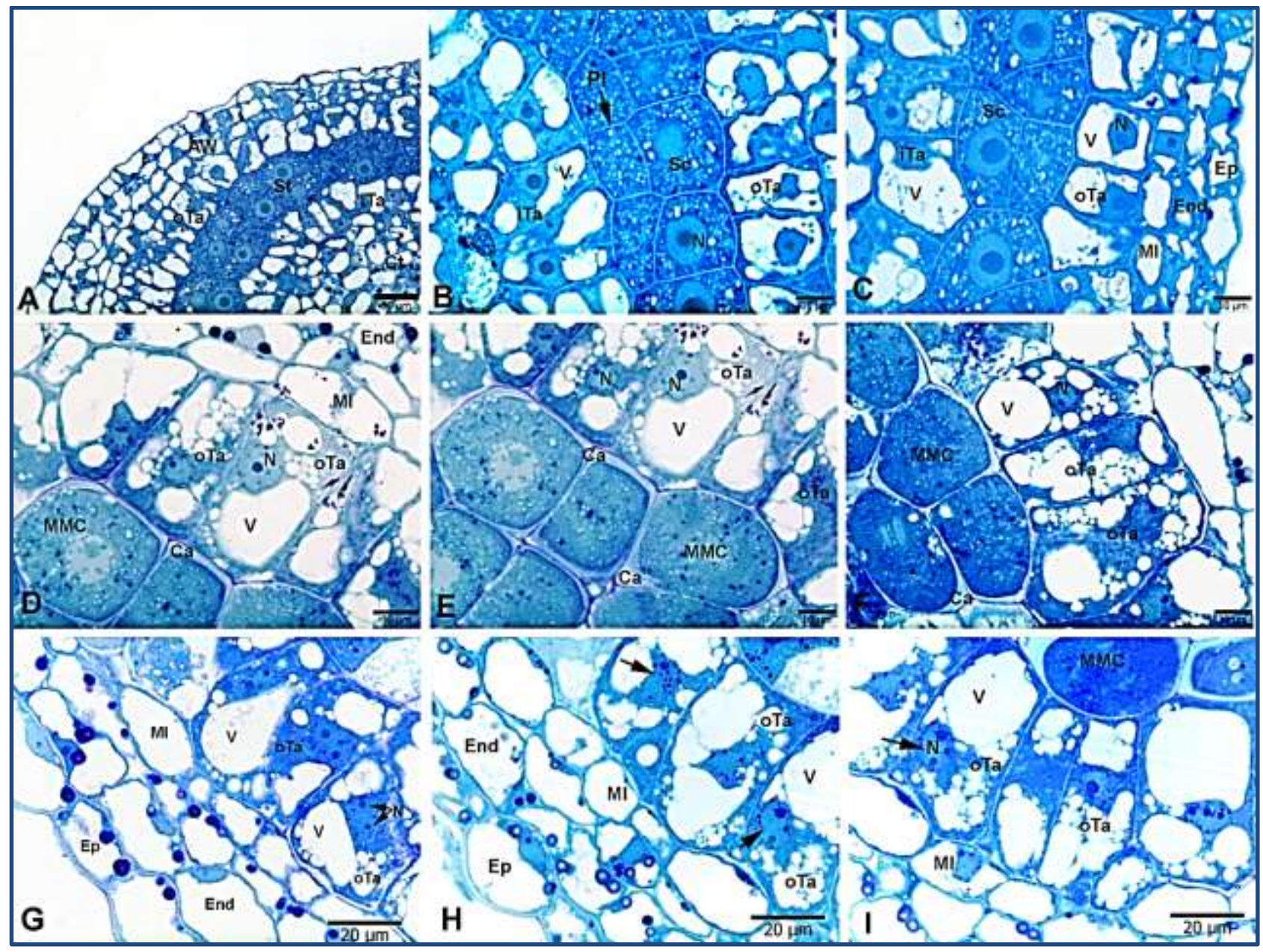

Fig. 2: Light micrographs of transverse semi-thin sections of anthers showing tapetal development at various stages of microsporogenesis. A-C- Tapetum development at sporogenous cell stage. D-F- Tapetum development just before the meiotic stage. G- Binucleate tapetal cells at the onset of meiotic division. H, I- Nuclear fusions at tapetal cells (arrows). (AW- anther wall, Ca- callose, Ct- connective tissue, End- endothecium, Ep- epidermis, Ml- middle layer, MMC- microspore mother cell, N- nucleus, Sc- sporogenous cell, St- sporogenous tissue, iTa- inner tapetum, oTa- outer tapetum, Pl- plasmodesmata,V- vacuole).

The tapetum of $C$. bignonioides anthers has a dual origin and dimorphic. The tapetum layer which differentiates from the inner secondary parietal layer and forms the innermost layer of the anther wall is called the outer tapetum, whereas that originates from the parenchymatous cells on the connective side adjacent to the sporogenous tissue is called the inner tapetum (Fig. 1A, B; 2A-C; 3A-C). Both the inner and outer tapetum contains single layered cells. Tapetal cells were uninucleate before the meiotic division of the microsporocytes (Fig. 2A-F), however, at the onset of the meiotic division, they began to be binucleate as a result of the nuclear divisions (Fig. 2G). Secondary nuclear divisions and nuclear fusions were also observed in tapetal cells (Fig. 2H, I).

At the early free tetrad microspore stage, Ubisch bodies were observed on the inner tangential surface of the tapetal cells. The inner tapetum started to degenerate at this stage, whereas, outer tapetum began to degenerate at the late free microspore tetrad stage (Fig. 3A-F). However, tapetal remains disappeared completely at the mature pollen grain stage. After the degeneration of tapetal cell walls, the tapetum formed a distinct tapetal membrane and Ubisch bodies attached to this membrane (Fig. 1F, G).

\section{Pollen development}

At the early sporogenous cell stage the anther wall had not yet completed its differentiation, however, as the development proceeded, it completed its differentiation, and finally, one layer of outer tapetum cells having large vacuoles was observed below the middle layer around sporogenous cells (Fig. 2A-I).

At the sporogenous cell stage, usually, two longitudinal rows of tightly packed, slightly polygonal sporogenous cells were observed in the crescent shaped anther locule of $C$. bignonioides (Fig. 2A-C). Sporogenous cells which had large centrally located nuclei were surrounded by thin cell walls and connected to each other by plasmodesmata (Fig. 2B). At the late sporogenous cell stage, the sporogenous cells gradually increased in volume and changed into microspore mother 
cells. Just before the prophase of the first meiotic division, callose accumulation began between the cell wall and the cell membrane of the microspore mother cells starting from the corners (Fig. 2D-F). After callose deposition completed, meiocytes separated from each other and underwent first and second meiotic division and simultaneous cytokinesis forming mostly tetrahedral and rarely isobilateral and linear tetrads. Following tetrad formation, callose envelope that surrounds the tetrads disappeared but microspores remained within the pollen mother cells cellulosic wall and failed to separate each other. As a result of this, the exine layer of the sporoderm was deposited on the group of four microspores (tetrads) instead of individual microspores and was released into anther locules as microspore tetrads (Fig. 3A-F). Herein the term microspore tetrad has been used to distinguish them from the normal tetrads.


Fig. 3. Light micrographs of transverse semi-thin sections through a single anther locule showing anther wall and microspore development at the free microspore tetrad stage. A- General view of an anther locule, anther wall, and the connective tissue. Note the crescent shape (horseshoe shaped) anther locule. B-F- Images of the same anther locule at different magnifications showing details of microspores and anther wall. Note the reserve materials (arrows in figure D) in the anther wall and microspores. (AL- anther locule, Ct- connective tissue, End- endothecium, Ep- epidermis, Ml- middle layer, MT- microspore tetrad, iTa- inner tapetum, oTa- outer tapetum, TR- remnants of the tapetum, Ub- Ubisch bodies, V-vacuole). 


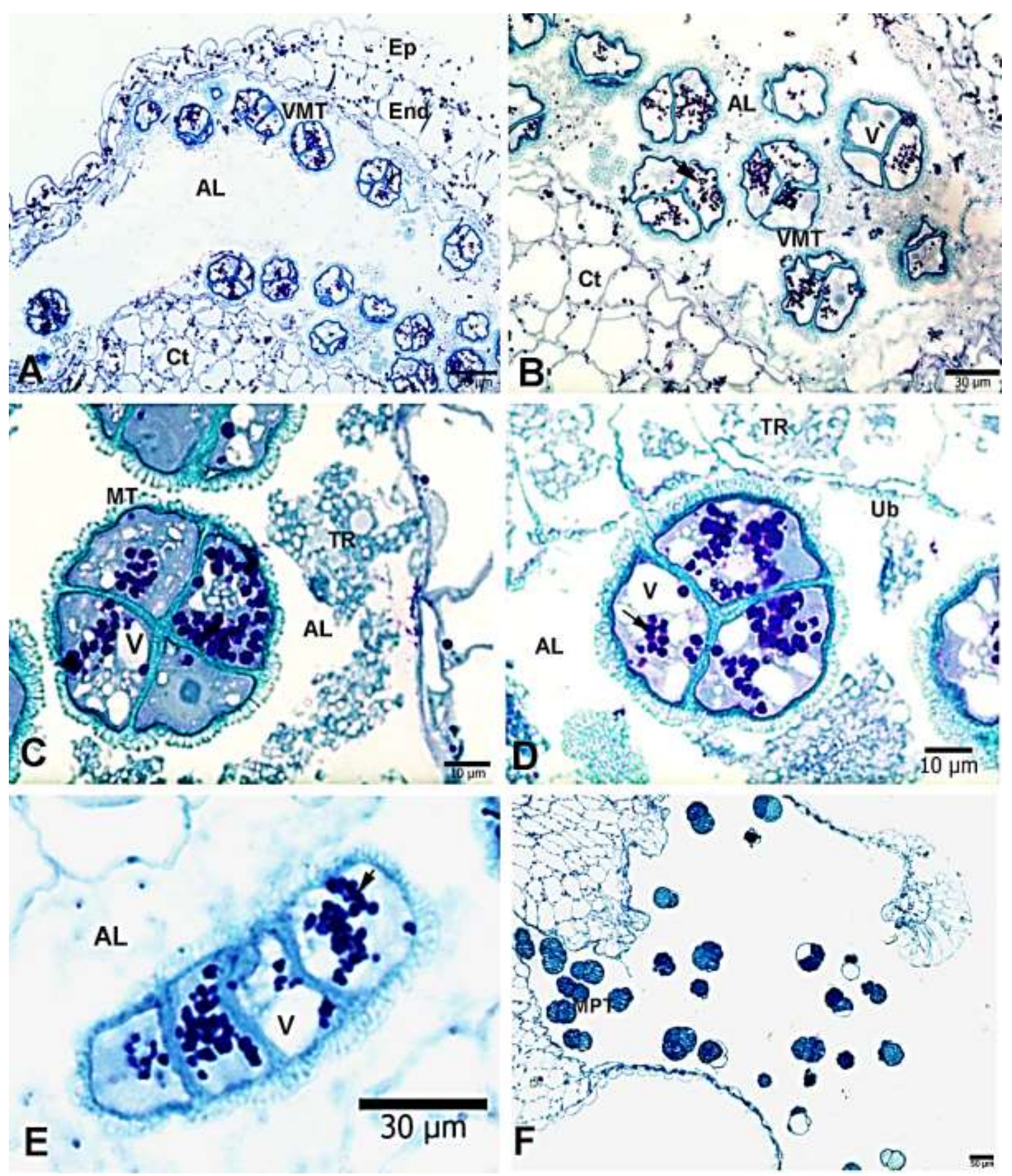

Fig. 4. Light micrographs of transverse semi-thin sections of anthers stained with toluidine blue. A- General view of an anther locule, anther wall and the connective tissue at the vacuolated microspore stage. B- General view of vacuolated microspore tetrads. C- Details of isobilateral microspore tetrad. D- Details of tetrahedral microspore tetrad. E- Details of linear microspore tetrad. F- General view of mature pollen tetrads at anthesis stage. (AL- anther locule, $\mathrm{Ct}$ - connective tissue, End- endothecium, Ep- epidermis, MT- microspore tetrad, MPT- mature pollen tetrads, TR- remnants of the tapetum, Ub- Ubisch bodies, V-vacuole, VMT-vacuolated microspore tetrad, Arrows show the reserve materials in vacuolated microspores.

At the free microspore tetrad stage, centrally located large nucleus and a moderate amount of small reserve materials were observed in the cytoplasm of each microspore (Fig. 3A-F). As the development progressed, vacuolization began in the cytoplasm and large reserve materials, presumably starch granules, appeared in the cytoplasm of the vacuolated microspores (Fig. 4A-E). The pollen wall (sporoderm) construction that has begun at the tetrad stage continued throughout the free microspore tetrad and vacuolated microspore tetrad stages by the addition of sporopollenin precursors originating from tapetum to the exine layer of the sporoderm. 
Similar to the vacuolated microspore tetrads, reserve materials were also present in the anther wall at the vacuolated microspore stage. However, concurrent to the formation of endothecial thickenings, the reserve materials in the anther wall started to decrease (Fig. 4A), and at the mature pollen grain stage, they disappeared completely (Fig. 4F) suggesting that reserve materials presumably consumed to provide energy for endothecial wall thickenings and cell enlargement. Furthermore, the decrease in the size and the numbers of reserve materials in the staminal envelope coincided with the increase in the number of reserve materials in the vacuolated microspores.

Following the first pollen mitosis, young bicellular pollen tetrads were produced and maturation period started. The mature pollen tetrads (compound pollen grains) of C. bignoniodies are inaperturate and "clypeate" type, that is exine shields have been separated by grooves (Fig. 5A-D). The sculpturing of the respective exine shields is reticulate (Fig. 5A-C). The compound pollen grains of $C$. bignoniodies are shed from the anther as tetrads (Fig. 4F).

\section{Discussion}

\section{Anther Wall}

The anthers of Catalpa bignonioides are tetrasporangiate as reported earlier for Catalpa bungei (Fan et al. 2011), Catalpa speciosa (Chen et al. 2014), and many other members of Bignoniaceae including Campsis radicans (Tütüncü Konyar \& Dane 2013b), Dolichandra unguis-cati (Bignonia unguis-cati), Kigelia africana (Kigelia pinnata), Markhamia lutea (Dolichandrone platycalyx), Millingtonia hortensis, Parmentiera aculeata (Parmentiera edulis) (Shivaramiah 1981), Pyrostagia venusta (Pyrostagia ignea) (Gupta \& Nanda 1978), Tecoma stans (Nanda \& Gupta 1978), T. smithii, Tabebuia ochracea (Bittencourt Jr. 1996), T. pallida, (Shivaramiah 1981). However, bisporangiate anthers have also been reported in some members of Bignoniaceae comprising Jacaranda mimosifolia (Galati \& Strittmatter 1999a).

The development of the anther wall of $C$. bignonioides conforms to the usual development in dicotyledons and other members of the Bignoniaceae such as $C$. radicans (Tütüncü Konyar \& Dane 2013b), P. venusta (Gupta \& Nanda 1978) and T. stans (Nanda \& Gupta 1978). The young anther wall consists of an epidermis, endothecium, middle layer, and the tapetum. However, at maturity, it consists of only epidermis and endothecium. The epidermal cells in the anther wall of $C$. bignonioides enlarge, become papillate and accumulate a thick layer of cuticle on their outer tangential walls as was also observed in C. radicans (Tütüncü Konyar et al. 2013), J. mimosifolia (Galati \& Strittmatter 1999a), T. ochracea (Bittencourt Jr. 1996) and T. pulcherrima (Bittencourt Jr. \& Mariath 1997). Davis (1966) had also described the radially enlarged epidermal cells with cutinized outer surface in Bignoniaceae. According to Garcia et al. (2002) enlarged epidermal cells in stomium region may enhance the anther dehiscence. Since radially enlarged epidermal cells were more prominent in the stomium region of $C$. bignonioides anthers, we also think that they play a role during anther dehiscence.

The number of endothecium layers in the anther wall of $C$. bignonioides ranges from 1 to 3 and, at maturity the endothecial cells develop U-shaped thickenings on their inner tangential and radial walls. The presence of multilayered endothecium and endothecial thickenings are not peculiar to $C$. bignonioides anthers, as in various angiosperms, they have also been reported in the other members of Bignoniaceae including $M$. lutea, $M$. hortensis, P. aculeate (Shivaramiah 1981), P. venusta (Gupta \& Nanda 1978), T. pallida, T. smithii (Shivaramiah 1981), T. stans (Nanda \& Gupta 1978). However, the types, formation time and location of thickenings on the endothecial wall show variations within the family. As an example in J. mimosifolia (Galati \& Strittmatter 1999a), endothecium develops fibrous thickenings only along the inner tangential walls, whereas in the present study U-shaped (crescent-shaped) thickenings were observed as reported earlier for $K$. africana (Shivaramiah 1981).

Generally, the tapetal development in C. Bignoniodes is similar to other descriptions of the secretory tapetum in dicotyledons and in the other members of the Bignoniaceae. The tapetum in C. bignonioides anthers is of the secretory type and shows a distinct dual origin as in many other members of Bignoniaceae including $C$. bungei (Fan et al. 2011), C. speciosa (Li et al. 2013, Chen et al. 2014), C. radicans (Tütüncü Konyar \& Dane 2013b), J. mimosifolia (Galati \& Strittmatter 1999a), M. hortensis (Shivaramiah 1981), P. venusta (Gupta \& Nanda 1978), T. stans (Nanda \& Gupta 1978), T. smithii (Shivaramiah 1981), T. ochracea (Bittencourt Jr. 1996), T. pulcherrima (Bittencourt Jr. \& Mariath 1997). On the other hand, amoeboid tapetum has also been reported in the other members of this family such as D. unguis-cati, K. africana and T. pallida (Shivaramiah 1981). The tapetum is usually single layered in Bignoniaceae. However, the number of tapetal nuclei shows variations between different species. The tapetal cells are ordinarily binucleate or multinucleate, and rarely uninucleate as was reported for K. africana (Shivaramiah, 1981). Binucleate tapetal cells have been described in $P$. venusta (Gupta \& Nanda 1978), P. aculeata, T. smithii (Shivaramiah 1981), T. stans (Nanda \& Gupta 1978), whereas multinucleated tapetal cells have been reported in M. lutea, M. hortensis, $T$. pallida (Shivaramiah 1981) and Oroxylum indicum (Ghatak 1956). In our previous study concerning the anther development in C. radicans (Tütüncü Konyar \& Dane 2013b), it was observed that the tapetal cells were multinucleated after secondary nuclear divisions but later they became binucleate as a result of nuclear fusions. However, multinucleate tapetal cells could be observed only in squashed preparations. 

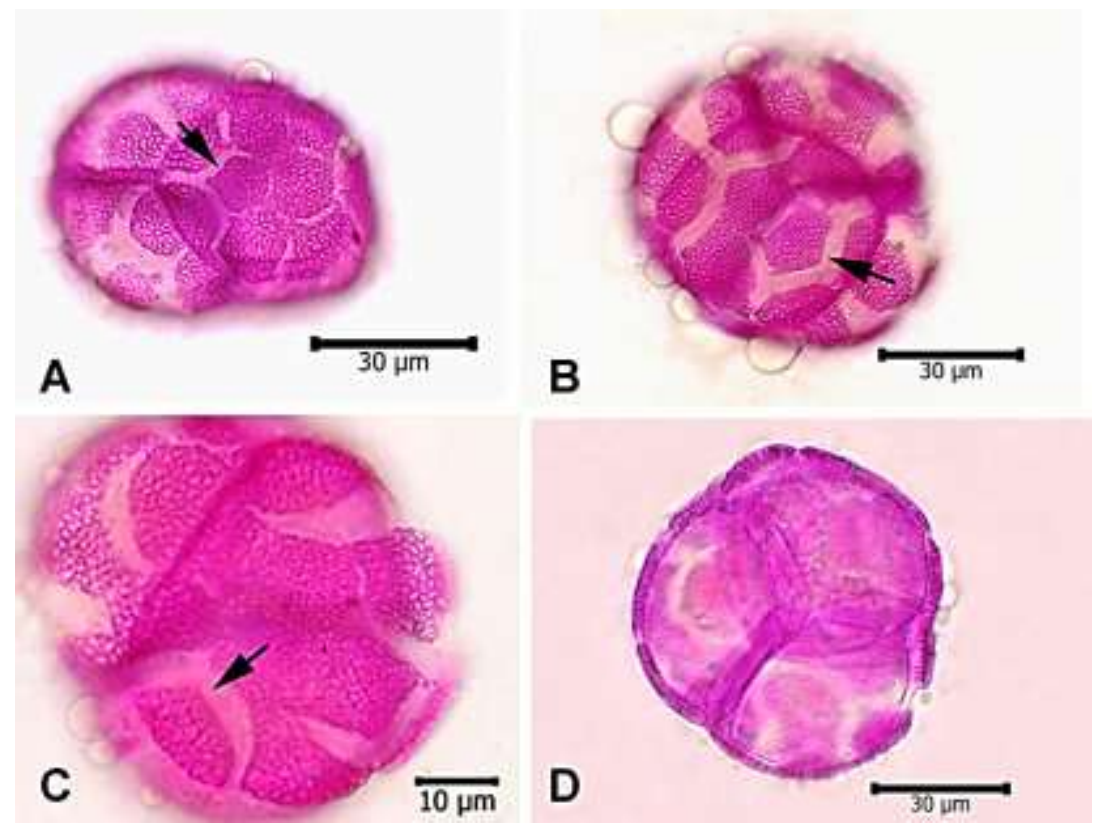

Fig. 5. Light micrographs of tetrad pollens (compound pollens) of $C$. bignonioides stained with basic fuchsine. A-C Show the details of "clypeate" pollens on which polygonal exine shields were separated by large grooves (arrows). Note the reticulate ornamentation of exine shields. D Pollen tetrad having a tetrahedral arrangement.

In transverse paraffin and semi- thin sections, we could observe only binucleate tapetal cells at the onset of the meiotic division (Tütüncü Konyar \& Dane 2013b). Therefore, it is obvious that to determine the presence or absence of the secondary nuclear divisions, nuclear fusions, and the number of nuclei in the tapetal cells evidently, very detailed investigation of the tapetal cells including numerous anthers at the different stages of the tapetal development, from premeiotic to tetrad stages, are necessary. The formation of the polyploid nucleus in multinucleate tapetal cells by nuclear fusions have also been reported in $M$. lutea, M. hortensis, T. pallida (Shivaramiah 1981) and O. indicum (Ghatak 1956).

Usually, nuclear divisions in the tapetal cells occur just before the meiotic division as was observed in $C$. radicans (Tütüncü Konyar \& Dane 2013b) or at the onset of the meiotic division. In the present study, we observed uninucleate tapetal cells in the anthers of $C$. bignonioides before the meiotic division. As the development of the anther proceeded, binucleate and trinucleate tapetal cells were observed indicating the presence of primary and secondary nuclear divisions in these cells. Furthermore, nuclear fusions were also observed in the tapetal cells.

At the free microspore stage, Ubisch bodies were observed on the inner tangential surface of the tapetal cells of $C$. bignonioides bordering the locules as reported earlier for C. radicans (Tütüncü Konyar \& Dane 2013b, Tütüncü Konyar 2014), J. mimosifolia (Galati \& Strittmatter 1999a, 1999b) P. venusta (Gupta \& Nanda 1978), T. stans (Nanda \& Gupta 1978), T. smithii (Shivaramiah 1981); T. ochracea (Bittencourt Jr. 1996), T. pulcherrima (Bittencourt Jr. \& Mariath 1997) and in many other species of Bignoniaceae studied by Mehra \&
Kulkarni (1986). However, in C. bignonioides, concurrent with the degeneration of the inner tangential walls of the tapetal cells, a new tapetal membrane was formed and Ubisch bodies attached to the inner surface of this tapetal membrane. Observations regarding the formation of tapetal membrane are consistent with the results of the previous studies including $C$. radicans (Tütüncü Konyar \& Dane 2013b, Tütüncü Konyar 2014), J. mimosifolia (Galati \& Strittmatter 1999a, 1999b), P. venusta (Gupta \& Nanda 1978), T. stans (Nanda \& Gupta 1978) and T. ochracea (Bittencourt Jr. 1996).

\section{Pollen Development}

At the sporogenous cell stage, usually two longitudinal rows of tightly packed, sporogenous cells were observed in the crescent shaped anther locule of $C$. bignonioides as was observed in $C$. radicans (Tütüncü Konyar \& Dane 2013b). Although the crescent shaped anther locule has been observed in all species of the Bignoniaceae investigated so far, the number of longitudinal rows of sporogenous cells vary in different species. As an example, single layered sporogenous tissue has been reported in J. mimosifolia (Galati \& Strittmatter 1999a).

Microspore and pollen development in $C$. bignonioides follows the basic scheme in angiosperms. As usual in angiosperms, microspore mother cells secrete callose wall before meiotic division. Meiocytes undergo meiosis and simultaneous cytokinesis resulting in the formation of tetrads mostly with a tetrahedral arrangement, and rarely isobilateral and linear arrangement. However, as observed rarely in angiosperms, following tetrad formation, callose envelope that surrounds the tetrads disappeared but 
microspores remained within the pollen mother cells cellulosic wall and failed to separate each other leading to the formation of compound pollen grains. The simultaneous cytokinesis and the formation of the tetrahedral and isobilateral tetrads, and compound pollen grains have also been reported in other species of the genus Catalpa including C. bungei (Fan et al. 2011), C. speciosa (Chen et al. 2014) and C. ovata (Ruwen 1981, Song et al. 2012).

Although the simultaneous cytokinesis and the tetrahedral tetrads have also been observed in other members of Bignoniaceae including $C$. radicans (Tütüncü

\section{References}

1. Armstrong, J.E. 1985. The Delimitation of Bignoniaceae and Scrophulariaceae Based on Floral Anatomy, and the Placement of Problem Genera. American Journal of Botany, 72: 755-766.

2. Bittencourt JR, N.S.1996. Microsporogenesis and the early male gametophyte development of Tabebuia ochracea (Cham.) Standley (Bignoniaceae). Acta Botanica Brasilica, 10(1): 9-23.

3. Bittencourt JR, N.S. \& Mariath, J.E.A. 1997. Ontogeny of the anther parietal layers of Tabebuia pulcherrima Sandwith (Bignoniaceae). Acta Botanica Brasilica, 11(1): 9-30.

4. Castillo, L. \& Rossini, C. 2010. Bignoniaceae metabolites as semiochemicals. Molecules, 15(10): 7090-7105.

5. Chen, X.H., Ding, R., Jiang, S., Xu, Y.F., Qu, B. \& Zhang, L.J. 2014. Megasporogenesis, Microsporogenesis and Formation of Female and Male Gametophyte of Catalpa specioca. Journal of Shenyang Agricultural University, 4: 408-412.

6. Choudhury, S., Datta, S., Talukdar, A.D. \& Choudhury, M.D. 2011. Phytochemistry of the family Bignoniaceae - a review. Assam University Journal of Science and Technology, 7: 145-150.

7. Craig, E.L., Frojola, W.J. \& Greider, M.H. 1962. An embedding technique for electron microscopy using Epon 812. The Journal of Cell Biology, 12(1):190-194.

8. Cragg, G.M. \& Newman D.J. 2005. Plants as a source of anti-cancer agents. Journal of Ethnopharmacology, 100(1): 72-79.

9. Davis, G.L. 1966. Systematic embryology of the angiosperms. John Wiley \& Sons, New York, 279pp.

10. Deka, D.C., Kumari V., Prasad, C., Kumar, K., Gogoi, B.J., Singh, L. \& Srivastava, R.B. 2013. Oroxylum indicum-a medicinal plant of North East India: An overview of its nutritional, remedial, and prophylactic properties. Journal of Applied Pharmaceutical Science, 3: 104-112.

11. De Abreu, M.B., Temraz, A., Vassallo, A., Braca, A. \& De Tommasi, N. 2014. Phenolic glycosides from Tabebuia argentea and Catalpa bignonioides. Phytochemistry Letters, 7: 85-88.

12. Dvorská, M., Žemlička, M., Muselík, J., Karafiátová, J. \& Suchý, V. 2007. Antioxidant activity of Catalpa bignonioides. Fitoterapia, 78: 437-439.
Konyar 2014), J. mimosifolia (Galati \& Strittmatter 1999a), T. ochracea (Bittencourt Jr. 1996) and $T$. pulcherrima (Bittencourt Jr. \& Mariath 1997), in all of these species, microspores separate each other at the end of the tetrad period and develop into single pollen grain.

The study of the anther wall and pollen development in C. bignonioides showed that the anther wall and pollen development follows the basic scheme in angiosperms and it coincides with the description of the process in the other species of the genus Catalpa. Therefore, we conclude that anther development in $C$. bignonioides can substantially be considered as normal.

13. Fan, L.L., Peng, F.R., Zhou, Q., Hao, M.Z \& Tan, P.P. 2011. Sporogenesis and Gametogenesis of Catalpa bungei (Bignoniaceae). Acta Botanica Boreali-Occidentalia Sinica, 3: 002.

14. Felter, H.W. \& Lloyd, J.U. 1989. Catalpa-Cigar Tree, King's American Dispensatory. (http://www.henriettesherbal.com/eclectic/kings/catalpa.ht ml) [Date accessed: April 2017].

15. Galati, B.G. \& Strittmatter, L.I. 1999a. Microsporogenesis and microgametogenesis in Jacaranda mimosifolia (Bignoniaceae). Phytomorphology, 49: 147-155.

16. Galati, B.G. \& Strittmatter, L.I. 1999b. Correlation between pollen development and Ubisch bodies ontogeny in Jacaranda mimosifolia (Bignoniaceae). Beiträge zur Biologie der Pflanzen, 71: 249-260.

17. García, M. A., Galati, B.G. \& Anton, A.M. 2002. Microsporogenesis, microgametogenesis and pollen morphology of Passiflora spp. (Passifloraceae). Botanical Journal of the Linnean Society, 139(4): 383-394.

18. Ghatak, J. 1956. A contribution to the life history of Oroxylum indicum Vent. Proceedings of the Indian Academy of Plant Sciences, 43(1): 72-87.

19. Gupta, S.C. \& Nanda, K. 1978. Studies in the Bignoniaceae. I. Ontogeny of Dimorphic Anter Tapetum in Pyrostagia. American Journal of Botany, 65: 395-399.

20. Hai-Yan, L.L.P.L. \& Chen, F.J. 2013. Observation on Megasporogenesis, Microsporogenesis and Development of Female and Male Gametophytes of Catalpa speciosa Warder. Bulletin of Botanical Research, 2: 004.

21. Harborne, J.B. 1967. Comparative biochemistry of the flavonoids. VI. Flavonoid patterns in the Bignoniaceae and the Gesneriaceae. Phytochemistry, 6: 1643-1651.

22. Inouye, H., Okuda, T. \& Hayashi, T. 1975. Quinones and related compounds in higher plants. II. Naphthoquinones and related compounds from Catalpa wood. Chemical and Pharmaceutical Bulletin, 23(2): 384-391.

23. Li, L.P., Liu, H.Y. \& Chen, F.J. 2013. Observation on Megasporogenesis, Microsporogenesis and Development of Female and Male Gametophytes of Catalpa speciosa Warder. Bulletin of Botanical Research, 33(2): 145-148.

24. Mehra, K.R. \& Kulkarni, A.R. 1986. Embryological studies in Bignoniaceae. Phytomorphology, 35: 239-251. 
25. Munoz-Mingarro, D., Acero, N., Llinares, F., Pozuelo, J.M., de Mera, A.G., Vicenten J.A. \& Perez, C. 2003. Biological activity of extracts from Catalpa bignonioides Walt. (Bignoniaceae). Journal of Ethnopharmacology, 87: 163-167.

26. Nanda, K. \& Gupta, S.C. 1978. Studies in the Bignoniaceae. II. Ontogeny of dimorphic anter tapetum in Tecoma. American Journal of Botany, 65: 400-405.

27. Nakaoki, T. \& Morita, N. 1955. Organic acids in the leaves of Catalpa ovata and Catalpa bignoniodies. Journal of the Pharmaceutical Society of Japan, 75: 171-172.

28. Olsen, R.T. \& Kirkbride, J.H. 2017. Taxonomic revision of the genus Catalpa (Bignoniaceae). Brittonia, 1-35.

29. Okuda, T., Yoshida, T. \& Ono, I. 1975. Two new flavone glycosides from Catalpa ovata. Phytochemistry, 14: 16541656.

30. Olmstead, R.G., Zjhra, M.L., Lohmann, L.G., Grose, S.O. \& Eckert, A.J. 2009. A molecular phylogeny and classification of Bignoniaceae. American Journal of Botany, 96: 1731-1743.

31. Pace, M.R., Lohmann, L.G., Olmstead, R.G. \& Angyalossy, V. 2015. Wood anatomy of major Bignoniaceae clades. Plant Systematics and Evolution, 301(3): 967-995.

32. Raghavan, T.S. \& Venkatasubban, K.R. 1940. Studies in Bignoniaceae. I. Chromosome number and epidermal hydatodes in Spathodea campanulata. Journal of Indian Botonical Society, 19: 293-298.
33. Rudramuniyappa, C.K. \& Mahajan, P.B. 1991. Histochemical and fluorescence microscopic study of anther development in Spathodea campanulata Beauv. Phytomorphology, 41: 175-188.

34. Ruwen, F. 1981. A study on the embryological development of Catalpa ovata. Journal of Nanjing Forestry University, 4: 64-74.

35. Shivaramiah, G. 1981. Embryological, palynological and histochemical studies in Bignoniaceae: Joseph's College Master's thesis, Bangalore, 36-44.

36. Song, X.Y., Yao, Y.F. \& Yang, W.D. 2012. Pollen analysis of natural honeys from the central region of Shanxi, North China. PloS one, 7: e49545.

37. Tütüncü Konyar, S. \& Dane, F. 2013a. Cytochemistry of pollen development in Campsis radicans (L.) Seem. (Bignoniaceae). Plant Systematics and Evolution, 299(1): 87-95.

38. Tütüncü Konyar, S. \& Dane, F. 2013b. Anther ontogeny in Campsis radicans (L.) Seem. (Bignoniaceae). Plant Systematics and Evolution, 299(3): 567-583.

39. Tütüncü Konyar, S., Dane, F. \& Tütüncü, S. 2013. Distribution of insoluble polysaccharides, neutral lipids and proteins in the developing anthers of Campsis radicans (L.) Seem. (Bignoniaceae). Plant Systematics and Evolution, 299(4): 743-760.

40. Tütüncü Konyar, S. 2014. Ultrastructure of microsporogenesis and microgametogenesis in Campsis radicans (L.) Seem. Plant Systematics and Evolution, 300(2): 303-320. 